\title{
DATA MINING: PENERAPAN RAPIDMINER DENGAN K-MEANS CLUSTER PADA DAERAH TERJANGKIT DEMAM BERDARAH DENGUE (DBD) BERDASARKAN PROVINSI
}

\author{
Kiki Fatmawati ${ }^{1}$, Agus Perdana Windarto ${ }^{2}$ \\ ${ }^{1,2}$ Sekolah Tinggi Ilmu Komputer Tunas Bangsa (STIKOM) Tunas Bangsa \\ Jl. Jendral Sudirman Blok A No/1/2/3 Pematangsiantar, Medan, Indonesia, 21127 \\ ${ }^{1}$ kikifatmawati@gmail.com, ${ }^{2}$ agus.perdana@amiktunasbangsa.ac.id
}

Abstrak-Penyakit Demam Berdarah Dengue (DBD) adalah penyakit yang disebabkan oleh virus Dengue yang tergolong Arthropod-Borne Virus, genus Flavivirus, dan famili Flaviviridae. DBD ditularkan melalui gigitan nyamuk dari genus Aedes, terutama Aedes aegypti atau Aedes albopictus. Penyakit DBD dapat muncul sepanjang tahun dan dapat menyerang seluruh kelompok umur. Penyakit ini berkaitan dengan kondisi lingkungan dan perilaku masyarakat. Penelitian ini membahas tentang pengelompokan jumlah daerah yang terjangkit demam berdarah dengue (DBD) berdasarkan provinsi. Metode yang digunakan adalah Data mining $K$ Means Clustering. Dengan menggunakan metode ini data-data yang telah diperoleh dapat dikelompokkan ke dalam beberapa cluster, dimana penerapan proses $K$-Means Clustering menggunakan tools RapidMiner. Penelitian ini menggunakan sumber data yang terekam di situs departemen kesehatan dengan alamat url https://www.depkes.go.id/. Data yang digunakan adalah (2014-2016) yang terdiri dari 34 provinsi. Kriteria yang digunakan, yakni: 1) jumlah kabupaten/kota dan 2) kabupaten/kota yang terjangkit. Data diolah dengan menggunakan $K$-means yang dibagi dalam 3 cluster yaitu: tingkat cluster tinggi (C1), tingkat cluster sedang (C2) dan tingkat cluster rendah (C3). Proses iterasi berlangsung 6 kali sehingga diperoleh penilaian dalam mengelompokkan daerah yang terjangkit demam berdarah dengue (DBD) berdasarkan provinsi. Hasil yang diperoleh bahwa terdapat 4 provinsi dengan cluster tingkatan tinggi (C1), 13 provinsi dengan cluster tingkatan sedang (C2), dan 17 provinsi dengan cluster tingkatan rendah (C3). Hal ini dapat menjadi masukan kepada masyarakat untuk menjaga kesehatan dengan meningkatkan kewaspadaan terhadap penularan demam berdarah, sehingga diperlukan kepedulian peran serta aktif masyarakat untuk bergotong-royong melakukan langkah-langkah pencegahan penularan penyakit DBD, melalui kegiatan pemberantasan nyamuk dan jentik secara berkala.

Kata Kunci-Demam Berdarah Dengue, Data Mining, K-means, Clustering

\section{PENDAHULUAN}

Penyakit Demam Berdarah Dengue (DBD) adalah penyakit yang disebabkan oleh virus Dengue yang tergolong Arthropod-Borne Virus, genus Flavivirus, dan famili Flaviviridae. DBD ditularkan melalui gigitan nyamuk dari genus Aedes, terutama Aedes aegypti atau Aedes albopictus. Penyakit DBD dapat muncul sepanjang tahun dan dapat menyerang seluruh kelompok umur. Penyakit ini berkaitan dengan kondisi lingkungan dan perilaku masyarakat. Adanya peran lingkungan dalam terjadinya penyakit dan wabah penyakit terjadi karena adanya interaksi antara manusia dengan lingkungan tidak selalu menguntungkan, kadang-kadang manusia bahkan dirugikan seperti terjangkit penyakit demam berdarah. Unsur lingkungan memegang peranan penting dalam menentukan terjadinya proses interaksi antara manusia dan unsur penyebab dalam proses terjadinya penyakit, kondisi lingkungan yang buruk memberi keuntungan virus penyakit cepat berkembang biak. Pembawa dan penyebar penyakit DBD yaitu Aedes aegypti menyukai lingkungan yang kualitasnya buruk, yang ditandai dengan permukiman padat penduduk dengan lingkungan yang kurang cahaya matahari, lembab, gelap, dekat dengan sungai dengan alirannya lambat karena adanya banyak sampah sehingga menimbulkan genangan sebagai tempat perkembangbiakan nyamuk Aedes aegypti. Ada dua faktor pembawa penyakit DBD yaitu Aedes aegypti dan Aedes albopictus, namun habitat kedua nyamuk ini sangatlah berbeda. Aedes aegypti yang lebih menyukai hidup di permukiman penduduk dan menyukai darah manusia, berbeda dengan Aedes albopictus yang habitatnya di kebun dan menghisap darah hewan. Nyamuk penular dengue ini terdapat hampir di seluruh pelosok Indonesia, kecuali di tempat yang memiliki ketinggian lebih dari 1000 meter di atas permukaan laut. Penyakit DBD banyak dijumpai terutama di daerah tropis dan sering menimbulkan kejadian luar biasa (KLB).

Beberapa tahun terakhir, kasus Demam Berdarah Dengue (DBD) seringkali muncul di musim pancaroba, khususnya bulan Januari di awal tahun. Karena itu, masyarakat perlu mengetahui penyebab penyakit DBD, mengenali tanda dan gejalanya, sehingga mampu mencegah dan menanggulangi dengan baik. Beberapa faktor yang mempengaruhi munculnya DBD antara lain rendahnya status kekebalan kelompok masyarakat dan kepadatan populasi nyamuk penular karena 
banyaknya tempat perindukan nyamuk yang biasanya terjadi pada musim penghujan. Pada tahun 2014, sampai pertengahan bulan Desember tercatat penderita DBD di 34 provinsi di Indonesia sebanyak 71.668 orang, dan 641 diantaranya meninggal dunia. Angka tersebut lebih rendah dibandingkan tahun sebelumnya, yakni tahun 2013 dengan jumlah penderita sebanyak 112.511 orang dan jumlah kasus meninggal sebanyak 871 penderita. Tahun 2016 terdapat jumlah kasus DBD sebanyak 204.171 kasus dengan jumlah kematian sebanyak 1.598 orang. Jumlah kasus DBD tahun 2016 meningkat dibandingkan jumlah kasus tahun 2015 (129.650 kasus). Jumlah kematian akibat DBD tahun 2016 juga meningkat dari tahun 2015 (1.071 kematian). IR atau angka kesakitan DBD tahun 2016 juga meningkat dari tahun 2015, yaitu 50,75 menjadi 78,85 per 100.000 penduduk. Namun, Case Fatality Rate (CFR) mengalami penurunan dari 0,83\% pada tahun 2015 menjadi 0,78\% pada tahun 2016 . Berikut tren angka kesakitan DBD selama kurun waktu 2010-2016.

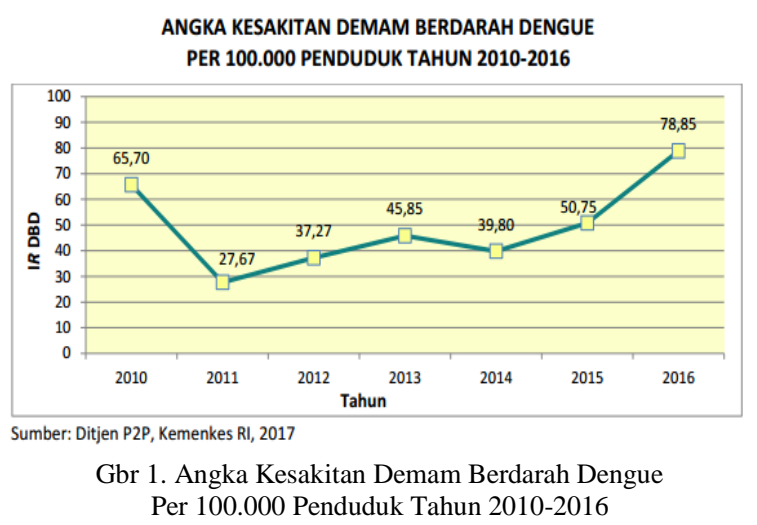

Berdasarkan Penelitian terdahulu yang dilakukan oleh Mahasiswa Departemen Statistika FSM Universitas Diponogoro, 2017 yang berjudul "Klasifikasi Diagnosa Penyakit Demam Berdarah Dengue (DBD) menggunakan Support Vector machine (SVM) berbasis GUI Matlab. Penelitian selanjutnya dilakukan oleh Aryu Chandra, 2010 yang berjudul "Demam berdarah dengue: Epidemiologi, Patogenesis, dan Faktor Resiko Penularan. Penelitian ini menjadi salah satu acuan penulis dalam melakukan penelitian sehingga penulis dapat memperkaya teori yang digunakan dalam mengkaji penelitian yang dilakukan. Dari penelitian terdahulu, penulis tidak menemukan penelitian dengan judul yang sama seperti judul penelitian penulis. Namun penulis mengangkat beberapa penelitian sebagai referensi dalam memperkaya bahan kajian pada penelitian penulis.

Berdasarkan penelitian diatas, maka peneliti mengangkat judul pengelompokan jumlah daerah yang terjangkit Demam Berdarah Dengue (DBD) berdasarkan provinsi Dengan K-Means Clustering. Diharapkan nantinya hasil penelitian yang didapatkan adalah daerah provinsi mana yang terkena penyakit demam berdarah dengue (DBD) paling tinggi. Ini dapat menjadi masukkan bagi pemerintah untuk memberikan kebijakan dalam mengembangkan pola hidup sehat kepada masyarakat tentang jumlah daerah yang terjangkit Demam Berdarah Dengue (DBD.

\section{LANDASAN TEORI}

\section{A. Data Mining}

Data mining merupakan proses menemukan korelasi baru yang bermanfaat, pola dan trend dengan menambang sejumlah repository data dalam jumlah besar, menggunakan teknologi pengenalan pola seperti statistik dan teknik matematika[1]. Data mining disebut juga dengan knowledge discovery in database (KDD) ataupun pattern recognition [2]. Data Mining dapat dibagi menjadi empat kelompok, yaitu model prediksi (prediction modelling), analisis kelompok (Cluster analysis), analisis asosiasi (association analysis) dan deteksi anomaly (anomaly detection)[3].

\section{B. Tahapan Data Mining}

Tahapan yang dilakukan pada proses data mining diawali dari seleksi data dari data sumber ke data target, tahap pre-processing untuk memperbaiki kualitas data, transformasi, data mining serta tahap interpretasi dan evaluasi yang menghasilkan output berupa pengetahuan baru yang diharapkan memberikan kontribusi yang lebih baik. Secara detail dijelaskan sebagai berikut [4]

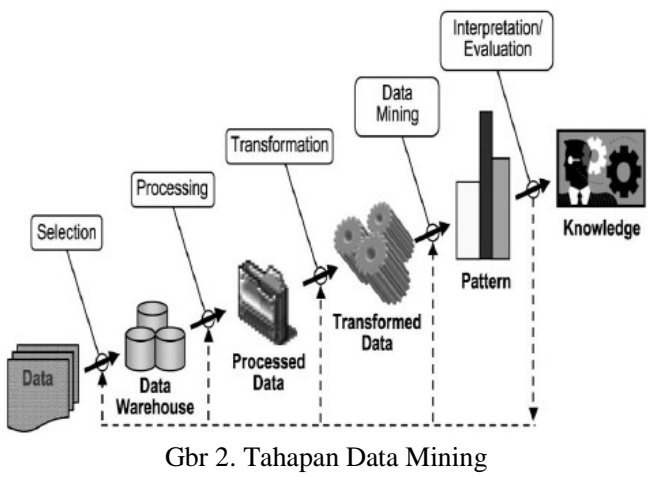

Berikut ini adalah penjelasan tahapan data mining berdasarkan gambar 2:

1. Data selection

Pemilihan (seleksi) data dari sekumpulan data operasional perlu dilakukan sebelum tahap penggalian informasi dalam KDD dimulai. Data hasil seleksi yang digunakan untuk proses data mining, disimpan dalam suatu berkas, terpisah dari basis data operasional.

\section{Pre-processing /cleaning}

Sebelum proses data mining dapat dilaksanakan, perlu dilakukan proses cleaning pada data yang menjadi fokus KDD. Proses cleaning mencakup antara lain membuang duplikasi data, memeriksa data yang inkonsisten, dan memperbaiki kesalahan pada data.

3. Transformation

Coding adalah proses transformasi pada data yang telah dipilih, sehingga data tersebut sesuai untuk 
proses data mining. Proses coding dalam KDD merupakan proses kreatif dan sangat tergantung pada jenis atau pola informasi yang akan dicari dalam basis data.

\section{Data mining}

Data mining adalah proses mencari pola atau informasi menarik dalam data terpilih dengan menggunakan teknik atau metode tertentu. Teknik, metode, atau algoritma dalam data mining sangat bervariasi. Pemilihan metode atau algoritma yang tepat sangat bergantung pada tujuan dan proses KDD secara keseluruhan.

\section{Interpretation/evalution}

Pola informasi yang dihasilkan dari proses data mining perlu ditampilkan dalam bentuk yang mudah dimengerti oleh pihak yang berkepentingan. Tahap ini merupakan bagian dari proses KDD yang disebut interpretation. Tahap ini mencakup pemeriksaan apakah pola atau informasi yang ditemukan bertentangan dengan fakta atau hipotesis yang ada sebelumnya.

\section{Clustering}

Clustering atau klasterisasi adalah metode pengelompokan data. Menurut Tan, 2006 clustering adalah sebuah proses untuk mengelompokkan data ke dalam beberapa cluster atau kelompok sehingga data dalam satu cluster memiliki tingkat kemiripan yang maksimum dan data antar cluster memiliki kemiripan yang minimum [5].

\section{K-Means}

K-means merupakan salah satu teknik pengelompokan yang bekerja berdasarkan partitioned clustering. Prinsip kerja dari pengelompokan hierarchical clustering dilakukan secara bertahap. Dan disetiap iterasi dari pengelompokan hierarchical clustering hanya ada satu pemilihan penggabungan suatu item terhadap item lainnya [6]. Langkah-langkah melakukan Clustering dengan metode K-Means adalah sebagai berikut [7]:

1. Pilih jumlah cluster k.

2. Inisialisasi $\mathrm{k}$ pusat cluster ini bisa dilakukan dengan

berbagai cara. Namun yang paling sering dilakukan adalah dengan cara random. Pusatpusat cluster diberi nilai awal dengan angkaangka random.

3. Alokasikan semua data/ objek ke cluster terdekat. Kedekatan dua objek ditentukan berdasarkan jarak kedua objek tersebut. Untuk menghitung jarak semua data ke setiap titik pusat cluster dapat menggunakan teori jarak Euclidean yang dirumuskan sebagai berikut:

$$
\begin{aligned}
& D(i j)= \\
& \sqrt{\left(X_{1 i}-X_{1 j}\right)^{2}+\left(X_{2 i}-X_{2 j}\right)^{2}+\cdots+\left(X_{k i}-X_{k j}\right)^{2}}
\end{aligned}
$$

dimana:

$D(I, j)=$ Jarak data ke $i$ ke pusat cluster $j$

$X k i=$ Data ke $i$ atribut data ke $k$

$X k j=$ Titik pusat ke $j$ pada atribut ke $k$

4. Hitung kembali pusat cluster dengan keanggotaan cluster yang sekarang. Pusat cluster adalah rata-rata dari semua data/objek dalam cluster tertentu. Jika dikehendaki bisa juga menggunakan median dari cluster tersebut. Jadi rata-rata (mean) bukan satu-satunya ukuran yang bisa dipakai.

$$
\begin{aligned}
& R_{k=\frac{1}{N_{k}}}\left(X_{1 k}+X_{2 k}+\cdots+X_{n k}\right) \\
& \text { dimana : } \\
& R k=\text { Rata-rata baru. } \\
& N k=\text { Jumlah training pattern pada cluster }(k) . \\
& X n k=\text { Pola ke }(n) \text { yang menjadi bagian } \\
& \quad \text { cluster }(k) .
\end{aligned}
$$

5. Tugaskan lagi tiap objek memakai pusat cluster yang baru. Jika pusat cluster tidak berubah lagi maka proses clustering selesai. Atau, kembali ke langkah nomor 3

\section{METODE PENELITIAN}

Dalam metodologi penelitian terdapat urutan kerangka kerja yang harus diikuti. Kerangka kerja ini merupakan langkah langkah yang dilakukan dalam penelitian. Adapun kerangka kerja yang digunakan dalam penelitian ini adalah seperti terlihat pada gambar dibawah ini.

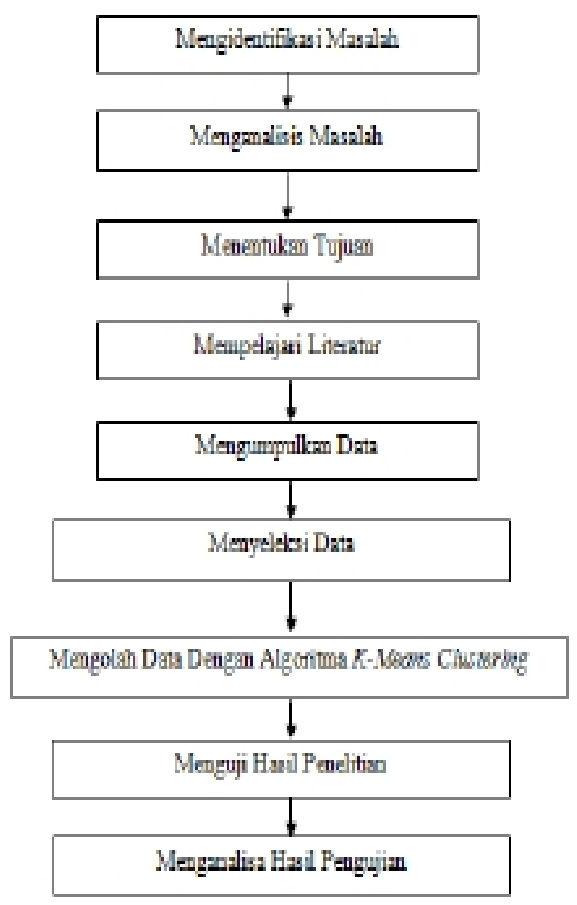

Gbr 3. Kerangka Kerja Penelitian 


\section{HASIL DAN PEMBAHASAN}

\section{A. Sumber Data}

Dalam penelitian ini, sumber data diambil dari Departemen Kesehatan dimana data tersebut merupakan data yang terjangkit demam berdarah Page |176 dengue (DBD) berdasarkan provinsi tahun 2014 2016. Dalam melakukan clustering, data yang diperoleh akan dihitung terlebih dahulu berdasarkan jumlah Kasus Penyakit DBD berdasarkan Provinsi. Hasil rata-rata berdasarkan 2 kriteria penilaian yakni 1). Rata-rata jumlah Kab/Kota 2). Rata-rata jumlah $\mathrm{Kab} /$ Kota yang terjangkit seperti yang ditunjukkan pada table berikut:

TABEL I

JUMLAH KABUPATEN/KOTA YANG TERJANGKIT DEMAM BERDARAH DENGUE BERDASARKAN PROVINSI (2014-

\begin{tabular}{|l|c|c|c|c|c|c|}
\hline \multicolumn{1}{|c|}{ Provinsi } & \multicolumn{7}{|c|}{ Jumlah Kab/Kota } & \multicolumn{2}{|c|}{ Kabupaten/Kota Terjangkit } \\
\cline { 2 - 7 } & $\mathbf{2 0 1 4}$ & $\mathbf{2 0 1 5}$ & $\mathbf{2 0 1 6}$ & $\mathbf{2 0 1 4}$ & $\mathbf{2 0 1 5}$ & $\mathbf{2 0 1 6}$ \\
\hline Aceh & 23 & 23 & 23 & 21 & 21 & 21 \\
\hline $\begin{array}{l}\text { Sumatera } \\
\text { Utara }\end{array}$ & 33 & 33 & 33 & 30 & 31 & 30 \\
\hline $\begin{array}{l}\text { Sumatera } \\
\text { Barat }\end{array}$ & 19 & 19 & 19 & 18 & 18 & 19 \\
\hline Riau & 12 & 12 & 12 & 12 & 10 & 12 \\
\hline Jambi & 11 & 11 & 11 & 10 & 11 & 11 \\
\hline $\begin{array}{l}\text { Sumatera } \\
\text { Selatan }\end{array}$ & 17 & 17 & 17 & 16 & 17 & 17 \\
\hline Bengkulu & 10 & 10 & 10 & 10 & 10 & 10 \\
\hline Lampung & 15 & 15 & 15 & 15 & 15 & 15 \\
\hline $\begin{array}{l}\text { Kep. Bangka } \\
\text { Belitung }\end{array}$ & 7 & 7 & 7 & 7 & 7 & 7 \\
\hline $\begin{array}{l}\text { Kepulauan } \\
\text { Riau }\end{array}$ & 7 & 7 & 7 & 5 & 7 & 6 \\
\hline DKI Jakarta & 6 & 6 & 6 & 5 & 6 & 6 \\
\hline Jawa Barat & 27 & 27 & 27 & 27 & 27 & 27 \\
\hline $\begin{array}{l}\text { Jawa } \\
\text { Tengah }\end{array}$ & 35 & 35 & 35 & 35 & 35 & 35 \\
\hline $\begin{array}{l}\text { DI } \\
\text { Yogyakarta }\end{array}$ & 5 & 5 & 5 & 5 & 5 & 5 \\
\hline Jawa Timur & 38 & 38 & 38 & 38 & 38 & 38 \\
\hline Banten & 8 & 8 & 8 & 8 & 8 & 8 \\
\hline Bali & 9 & 9 & 9 & 9 & 9 & 9 \\
\hline NTB & 10 & 10 & 10 & 10 & 10 & 10 \\
\hline NTT & 22 & 22 & 22 & 6 & 11 & 11 \\
\hline KalBar & 14 & 14 & 14 & 14 & 14 & 14 \\
\hline KalTeng & 14 & 14 & 14 & 14 & 14 & 14 \\
\hline KalSel & 13 & 13 & 13 & 13 & 13 & 13 \\
\hline KalTim & 10 & 10 & 10 & 10 & 10 & 10 \\
\hline KalUt & 5 & 5 & 5 & 5 & 5 & 5 \\
\hline $\begin{array}{l}\text { Sulawesi } \\
\text { Utara }\end{array}$ & 15 & 15 & 15 & 14 & 14 & 15 \\
\hline $\begin{array}{l}\text { Sulawesi } \\
\text { Tengah }\end{array}$ & 13 & 13 & 13 & 13 & 12 & 13 \\
\hline $\begin{array}{l}\text { Sulawesi } \\
\text { Selatan }\end{array}$ & 24 & 24 & 24 & 22 & 23 & 24 \\
\hline $\begin{array}{l}\text { Sulawesi } \\
\text { Tenggara }\end{array}$ & 14 & 17 & 17 & 9 & 12 & 16 \\
\hline Gorontalo & 6 & 6 & 6 & 6 & 6 & 6 \\
\hline $\begin{array}{l}\text { Sulawesi } \\
\text { Barat }\end{array}$ & 6 & 6 & 6 & 6 & 5 & 5 \\
\hline Maluku & 11 & 11 & 11 & 4 & 6 & 8 \\
\hline $\begin{array}{l}\text { Maluku } \\
\text { Utara }\end{array}$ & 10 & 10 & 10 & 6 & 6 & 8 \\
\hline Papua Barat & 13 & 13 & 13 & 3 & 5 & 5 \\
\hline Papua & 29 & 29 & 29 & 7 & 5 & 10 \\
\hline
\end{tabular}

Data tersebut kemudian diakumulasikan dan diambil nilai rata-rata dari setiap kriteria seperti yang ditunjukkan pada tabel 2 berikut:
TABEL II

DATA RATA-RATA JUMLAH KABUPATEN/KOTA YANG TERJANGKIT DEMAM BERDARAH DENGUE BERDASARKAN PROVINSI TAHUN 2014 - 2016

\begin{tabular}{|c|c|c|c|c|c|c|c|c|}
\hline \multirow{3}{*}{ Provinsi } & \multicolumn{3}{|c|}{ Jumlah Kab/Kota } & \multirow{3}{*}{$\begin{array}{c}\text { Rata- } \\
\text { rata }\end{array}$} & \multicolumn{3}{|c|}{ Kabupaten/Kota Terjangkit } & \multirow{3}{*}{$\begin{array}{l}\text { Rata- } \\
\text { rata }\end{array}$} \\
\hline & \multirow{2}{*}{2014} & \multirow{2}{*}{2015} & \multirow{2}{*}{2016} & & 2014 & 2015 & 2016 & \\
\hline & & & & & Jumlah & Jumlah & Jumlah & \\
\hline Aceh & 23 & 23 & 23 & 23 & 21 & 21 & 21 & 21 \\
\hline $\begin{array}{l}\text { Sumatera } \\
\text { Utara }\end{array}$ & 33 & 33 & 33 & 33 & 30 & 31 & 30 & 30,333 \\
\hline $\begin{array}{l}\text { Sumatera } \\
\text { Barat } \\
\end{array}$ & 19 & 19 & 19 & 19 & 18 & 18 & 19 & 18,333 \\
\hline Riau & 12 & 12 & 12 & 12 & 12 & 10 & 12 & 11,333 \\
\hline Jambi & 11 & 11 & 11 & 11 & 10 & 11 & 11 & 10,667 \\
\hline $\begin{array}{l}\text { Sumatera } \\
\text { Selatan }\end{array}$ & 17 & 17 & 17 & 17 & 16 & 17 & 17 & 16,667 \\
\hline Bengkulu & 10 & 10 & 10 & 10 & 10 & 10 & 10 & 10 \\
\hline Lampung & 15 & 15 & 15 & 15 & 15 & 15 & 15 & 15 \\
\hline $\begin{array}{l}\text { Kep. } \\
\text { Bangka } \\
\text { Belitung }\end{array}$ & 7 & 7 & 7 & 7 & 7 & 7 & 7 & 7 \\
\hline $\begin{array}{l}\text { Kepulauan } \\
\text { Riau }\end{array}$ & 7 & 7 & 7 & 7 & 5 & 7 & 6 & 6 \\
\hline $\begin{array}{l}\text { DKI } \\
\text { Jakarta } \\
\end{array}$ & 6 & 6 & 6 & 6 & 5 & 6 & 6 & 5,667 \\
\hline Jawa Barat & 27 & 27 & 27 & 27 & 27 & 27 & 27 & 27 \\
\hline $\begin{array}{l}\text { Jawa } \\
\text { Tengah }\end{array}$ & 35 & 35 & 35 & 35 & 35 & 35 & 35 & 35 \\
\hline $\begin{array}{l}\text { DI } \\
\text { Yogyakarta }\end{array}$ & 5 & 5 & 5 & 5 & 5 & 5 & 5 & 5 \\
\hline $\begin{array}{l}\text { Jawa } \\
\text { Timur }\end{array}$ & 38 & 38 & 38 & 38 & 38 & 38 & 38 & 38 \\
\hline Banten & 8 & 8 & 8 & 8 & 8 & 8 & 8 & 8 \\
\hline Bali & 9 & 9 & 9 & 9 & 9 & 9 & 9 & 9 \\
\hline NTB & 10 & 10 & 10 & 10 & 10 & 10 & 10 & 10 \\
\hline NTT & 22 & 22 & 22 & 22 & 6 & 11 & 11 & 9,333 \\
\hline KalBar & 14 & 14 & 14 & 14 & 14 & 14 & 14 & 14 \\
\hline KalTeng & 14 & 14 & 14 & 14 & 14 & 14 & 14 & 14 \\
\hline KalSel & 13 & 13 & 13 & 13 & 13 & 13 & 13 & 13 \\
\hline KalTim & 10 & 10 & 10 & 10 & 10 & 10 & 10 & 10 \\
\hline KalUt & 5 & 5 & 5 & 5 & 5 & 5 & 5 & 5 \\
\hline $\begin{array}{l}\text { Sulawesi } \\
\text { Utara }\end{array}$ & 15 & 15 & 15 & 15 & 14 & 14 & 15 & 14,333 \\
\hline $\begin{array}{l}\text { Sulawesi } \\
\text { Tengah }\end{array}$ & 13 & 13 & 13 & 13 & 13 & 12 & 13 & 12,667 \\
\hline $\begin{array}{l}\text { Sulawesi } \\
\text { Selatan }\end{array}$ & 24 & 24 & 24 & 24 & 22 & 23 & 24 & 23 \\
\hline $\begin{array}{l}\text { Sulawesi } \\
\text { Tenggara } \\
\end{array}$ & 14 & 17 & 17 & 16 & 9 & 12 & 16 & 12,333 \\
\hline Gorontalo & 6 & 6 & 6 & 6 & 6 & 6 & 6 & 6 \\
\hline $\begin{array}{l}\text { Sulawesi } \\
\text { Barat }\end{array}$ & 6 & 6 & 6 & 6 & 6 & 5 & 5 & 5,333 \\
\hline Maluku & 11 & 11 & 11 & 11 & 4 & 6 & 8 & 6 \\
\hline $\begin{array}{l}\text { Maluku } \\
\text { Utara }\end{array}$ & 10 & 10 & 10 & 10 & 6 & 6 & 8 & 6,667 \\
\hline $\begin{array}{l}\text { Papua } \\
\text { Barat }\end{array}$ & 13 & 13 & 13 & 13 & 3 & 5 & 5 & 4,333 \\
\hline Papua & 29 & 29 & 29 & 29 & 7 & 5 & 10 & 7,333 \\
\hline
\end{tabular}

Setelah diakumulasikan dan dicari nilai rata-rata maka akan didapatkan nilai dari setiap variabel. Data tersebut masuk ke tahapan clustering dan diolah dengan $\mathrm{K}$-means berdasarkan cluster yang sudah ditentukan.

\section{B. Cendroid Data}

Dalam penerapan algoritma K-means dihasilkan nilai titik tengah atau centroid dari data. Proses pencarian nilai titik tengah dilakukan dengan mengambil nilai terbesar (maksimum) untuk cluster tingkat tinggi (C1), 
nilai rata-rata (average) untuk cluster tingkat sedang (C2) dan nilai terkecil (minimum) untuk cluster tingkat rendah (C3). Berikut ini nilai centroid awal untuk iterasi 1 dapat diketahui pada tabel berikut:

Page | 177

CENTROID DATA AWAL (ITERASI 1)
\begin{tabular}{|l|c|c|}
\hline \multicolumn{3}{|c|}{ Centroid } \\
\hline Max (C1) & 38 & 38 \\
\hline Average (C2) & 15,09 & 13,16 \\
\hline Min (C3) & 5 & 4,33 \\
\hline
\end{tabular}

\section{Clustering Data}

Proses clustering dengan menggunakan nilai centroid awal yang terdapat pada tabel 3, akan memperoleh hasil pengelompokan pada iterasi 1 yang dapat dilihat pada tabel dibawah ini:

TABEL IV

PENGELOMPAKAN DATA ITERASI 1

\begin{tabular}{|c|c|c|c|}
\hline Provinsi & C1 & $\mathrm{C} 2$ & C3 \\
\hline Aceh & & 1 & \\
\hline Sumatera Utara & 1 & & \\
\hline Sumatera Barat & & 1 & \\
\hline Riau & & 1 & \\
\hline Jambi & & 1 & \\
\hline Sumatera Selatan & & 1 & \\
\hline Bengkulu & & 1 & \\
\hline Lampung & & 1 & \\
\hline Kepulauan Bangka Belitung & & & 1 \\
\hline Kepulauan Riau & & & 1 \\
\hline DKI Jakarta & & & 1 \\
\hline Jawa Barat & 1 & & \\
\hline Jawa Tengah & 1 & & \\
\hline DI Yogyakarta & & & 1 \\
\hline Jawa Timur & 1 & & \\
\hline Banten & & & 1 \\
\hline Bali & & & 1 \\
\hline Nusa Tenggara Barat & & 1 & \\
\hline Nusa Tenggara Timur & & 1 & \\
\hline Kalimantan Barat & & 1 & \\
\hline Kalimantan Tengah & & 1 & \\
\hline Kalimantan Selatan & & 1 & \\
\hline Kalimantan Timur & & 1 & \\
\hline Kalimantan Utara & & & 1 \\
\hline Sulawesi Utara & & 1 & \\
\hline Sulawesi Tengah & & 1 & \\
\hline Sulawesi Selatan & & 1 & \\
\hline Sulawesi Tenggara & & 1 & \\
\hline Gorontalo & & & 1 \\
\hline Sulawesi Barat & & & 1 \\
\hline Maluku & & & 1 \\
\hline Maluku Utara & & & 1 \\
\hline Papua Barat & & & 1 \\
\hline Papua & & 1 & \\
\hline Hasil & 4 & 18 & 12 \\
\hline
\end{tabular}

Berdasarkan tabel 4, diperoleh pengelompokan untuk iterasi 1: Cluster tingkat tinggi (C1) terdiri dari
4 provinsi yakni Sumatera Utara, Jawa Barat, Jawa Tengah, Jawa Timur, cluster tingkat sedang (C2) terdiri dari 18 provinsi yakni Aceh, Sumatera Barat, Riau, Jambi, Sumatera Selatan, Bengkulu, Lampung, NTB, NTT, KalBar, KalTeng, KalSel, KalTim, Sulawesi Utara, Sulawesi Tengah, Sulawesi Tenggara, Sulawesi Selatan, Papua dan cluster tingkat rendah (C3) terdiri dari 12 provinsi yakni Kep. Bangka Belitung, Kep. Riau, DKI Jakarta, Yogyakarta, Banten, Bali, KalUt, Gorontalo, Sulawesi Barat, Maluku, Maluku Utara, Papua Barat, Papua. Proses iterasi akan terus berlangsung sampai hasil iterasi terakhir sama dengan hasil iterasi sebelumnya. Proses nilai titik tengah atau centroid akan menyesuaikan sesuai dengan iterasi yang ada. Dalam hal ini proses akan dilanjutkan dengan menggunakan aplikasi RapidMiner.

D. Penerapan aplikasi RapidMiner

Hasil pengelompokan data daerah terjangkit Demam Berdarah Dengue (DBD) berdasarkan provinsi dengan

Rapid

Miner :

1. Data view: merupakan sheet di Result Perspective untuk menampilkan data yang telah diolah secara keseluruhan lengkap dengan klasternya dari example set (read excel). Data view dapat lihat pada gambar.

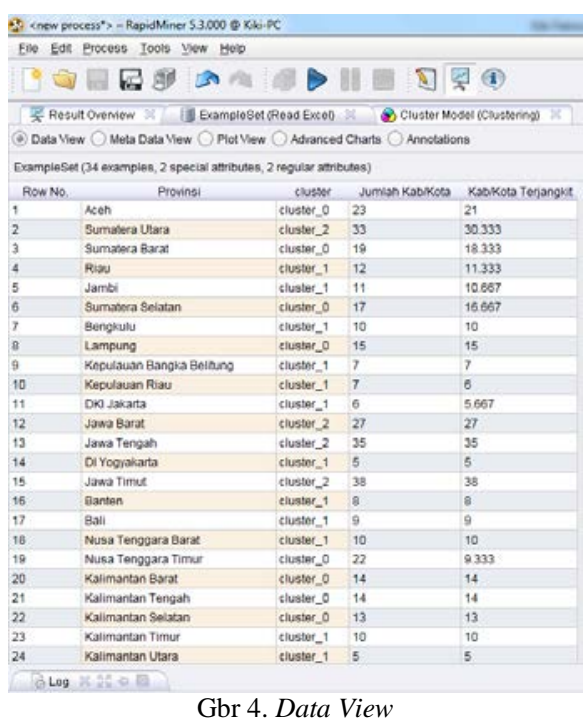

2. Flot view : merupakan sheet di Result Perspective untuk menampilkan data yang telah diolah secara keseluruhan lengkap dengan klasternya dari example set (read excel) dalam bentuk diagram Scatter. Tampilannya dapat dilihat pada gambar berikut 
Page | 178

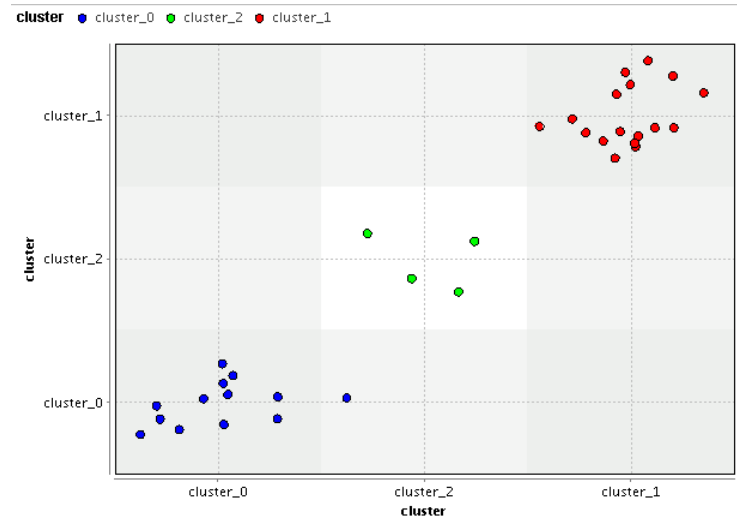

Gbr 5. Hasil Clustering

3. Text view : merupakan sheet untuk menampilkan database yang telah diolah secara keseluruhan lengkap dengan clusternya. Tampilan dari cluster model (clustering) dapat lihat pada gambar berikut.

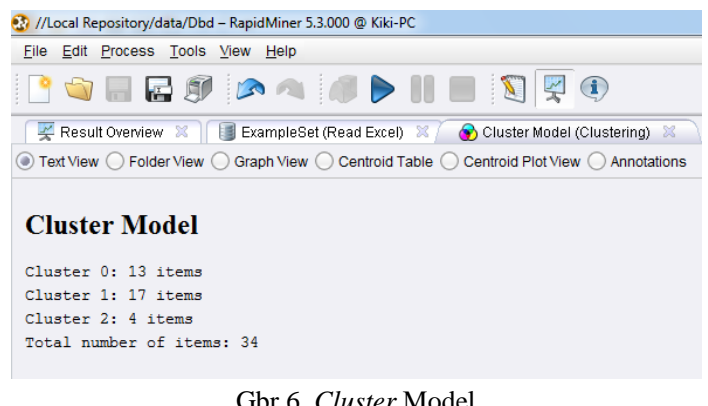

4. Folder view : merupakan sheet untuk menampilkan database yang telah diolah secara keseluruhan lengkap dengan clusternya. Tampilan folder view dapat dilihat pada gambar berikut.

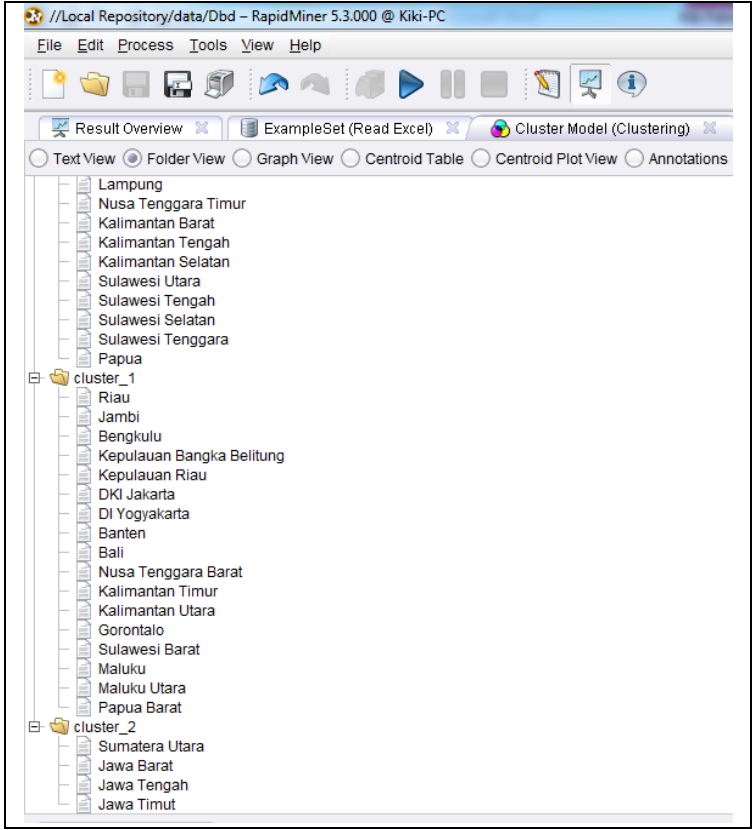

Gbr 7. Folder View

\section{KESIMPULAN}

Dari hasil penelitian yang telah dilakukan, maka penulis dapat menarik beberapa kesimpulan, diantaranya sebagai berikut

1. Pengujian yang dilakukan dalam penelitian ini, iterasi clustering pada data penyakit DBD (Demam Berdarah Dengue) terjadi sebanyak 6 kali iterasi.

2. Data tersebut diolah menggunakan Rapidminner untuk ditentukan nilai centroid dalam 3 cluster yaitu cluster tingkat tinggi (C1), cluster tingkat sedang (C2) dan cluster tingkat rendah (C3).

3. Dari 34 data jumlah kasus yang terjangkit Demam Berdarah Dengue (DBD) berdasarkan provinsi dapat diketahui, 4 provinsi cluster tingkat tinggi untuk penderita kasus DBD yakni Sumatera Utara, , Jawa Barat, Jawa Tengah dan Jawa Timur, 13 provinsi cluster tingkat sedang dan 17 provinsi lainnya termasuk cluster tingkat rendah.

\section{UCAPAN TERIMA KASIH}

Terima kasih kepada Bapak Agus Perdana Windarto yang membimbing dalam penulisan serta STIKOM Tunas Bangsa Pematangsiantar khususnya program studi Sistem Informasi yang telah menyediakan sarana dan prasarana selama penelitian ini berlangsung.

\section{REFERENSI}

[1] C. J. M. S. Fina Nasari, "Penerapan Algoritma K-Means Clustering Untuk Pengelompokkan Penyebaran Diare Di Kabupaten Langkat,” pp. 108-119.

[2] A. P. Windarto, "Implementation of Data Mining on Rice Imports by Major Country of Origin Using Algorithm Using K-Means Clustering Method,” Int. J. Artif. Intell. Res., vol. 1, no. 2, pp. 26-33, 2017.

[3] S. Mulyati, "Penerapan Data Mining Dengan Metode Clustering Untuk Pengelompokan Data Pengiriman Burung," vol. 1, no. Senatkom, 2015.

[4] A. P. Windarto, "Penerapan Data Mining Pada Ekspor BuahBuahan Menurut Negara Tujuan Menggunakan K-Means Clustering,” Techno.COM, vol. 16, no. 4, pp. 348-357, 2017.

[5] N. Aggarwal, K. Aggarwal, and K. Gupta, "Comparative Analysis of K-means and Enhanced K-means Clustering Algorithm for Data Mining,” Int. Jouranl Sci. Eng. Res., vol. 3, no. 3, 2012.

[6] Y. Siyamto and Program, "Pemanfaatan Data Mining Dengan Metode Clustering Untuk Evaluasi Biaya Dokumen Ekspor,” vol. 1, no. 2, pp. 28-31, 2017.

[7] R. Hidayat, R. Wasono, and M. Y. Darsyah, "Pengelompokan Kabupaten / Kota Di Jawa Tengah,” pp. 240-250, 2017. 